\title{
Trophallactic interactions in the adult honeybee (Apis mellifera L.)
}

\author{
Karl Crailsheim \\ Institut für Zoologie an der Karl-Franzens-Universtität, Universitätsplatz 2, \\ A-8010 Graz, Austria
}

(Received 15 August 1997; accepted 18 November 1997)

\begin{abstract}
Trophallaxis, the transfer of food by mouth from one individual to another, occurs among adults of honeybee colonies. The drones and the queen consume but do not donate, while the workers are recipients and donors. They share the content of their crops and sometimes the products of their head glands. Such trophallactic interactions can frequently be seen non-randomly between all members of the colony. Their occurrence and success depend on factors such as sex and age of the consumers and donors, food availability and quality, time of day, weather and season. For the youngest workers, old workers, drones and the queen this flow - especially the flow of protein - has definite nutritional importance, since these bees need protein but have only a limited capacity to digest pollen and consume none or only small amounts of it. The system of trophallactic food flow and the existence of a specialised group, the nurses, who are responsible for consuming pollen and processing it as easily digestible jelly enables the colony to have many members with a reduced digesting capacity. The food storer bees specialise in transporting harvested nectar within the hive, receiving it from foragers near the entrance and depositing it in other parts of the hive where it is processed into honey. This saves time and helps the foragers to harvest available food sources more efficiently. In addition to its nutritional value and the importance of transfer to specialists, receiving and donating food in the trophallactic flow of food provides information to colony members about the quality and quantity of food existing in the hive and can therefore be compared in its importance with the dance language and communication by pheromones. (1nra/DIB/AGIB/Elsevier, Paris
\end{abstract}

\section{Apis mellifera / trophallaxis / division of labour / language / nutrition}

\section{INTRODUCTION}

In summer honeybee colonies consist of some thousands of larvae and pupae, workerbees, some hundreds of drones and the queen. Drones and queens are responsible for the reproduction. A mated queen can lay eggs over several years. The drones die after copulation. After the first day following emergence the workers run

* Correspondence and reprints

Tel.: (43) 316380 5616; fax: (43) 316380 9875; e-mail: karl.crailsheim@kfunigraz.ac.at 
through a system of division of labour, starting with cleaning, brood and queen care, comb building (including wax synthesis), food preparation and storage, and finally defence of the colony and foraging for nectar, pollen, water and resin (simplified after Rösch, 1925; Lindauer, 1952; Free, 1965; Seeley, 1982; Kolmes, 1985). This succession is not strictly age dependent, but is modified by factors such as genetics (Calderone and Page, 1988; Rothenbuhler and Page, 1989), by juvenile hormone (Robinson, 1987; Huang and Robinson, 1992), the needs of the colony (Ribbands, 1952), environmental conditions or food availability.

In addition to the dance language (von Frisch, 1965) and pheromones (Free, 1987; Winston, 1987; Winston et al., 1989, 1990, 1991; Higo et al., 1992), trophallactic interactions - the donating of food from one bee to another one - is an important factor in making the complex social community work (cf. Free, 1959).

\section{TROPHALLACTIC BEHAVIOUR}

The trophallaxis behaviour between workers is described in detail by Free (1956, 1957a) and Korst and Velthuis (1982). A recipient asks for food by protruding her tongue towards the mandibles of another bee, termed the donor if the contact leads to a transfer. The antennae of the recipient are directed towards the donor. The donor's antennae are kept more or less downward and close to the head. The antennae of both animals touch each other frequently (Istomina-Tsvetkova, 1960). This antennal contact is important (Montagner and Pain, 1971); if it is hindered by partial or total amputation, the success of transfer is reduced (Free, 1956; Pain et al., 1978; Galliot and Azoeuf, 1979). A donor may offer food with or without being asked. A food droplet, the size of which may vary, is kept between the mandibles and the prementum, and is sucked by the recipient's tongue. A transfer to a worker might last from a few seconds up to some minutes (IstominaTsvetkova, 1960; Korst and Velthuis, 1982). It can be very fast, maximum speed of transfer was observed with $1.6 \mu \mathrm{L}$ per second (Farina and Nunez, 1991). But in cage experiments even if attempts last more than $10 \mathrm{~s}$, they are not necessarily successful (Korst and Velthuis, 1982). Korst and Velthuis (1982) further discuss the role of pheromones or the smell of offered food, and Free (1956) the importance of the head volatiles, as factors involved in the initiation of trophallactic contacts. He demonstrated that even heads of dead bees were approached as potential donors.

Queens are fed extensively by the workers (Allen, 1955). Allen (1960) reported an average feeding duration of $44 \mathrm{~s}$ during the breeding season. The feeding of drones looks similar to the feeding of workers (Othani, 1974). The drones use their front legs in addition to their antennae to keep contact with the donor worker. Duration of drone feedings in colonies last from some seconds to $150 \mathrm{~s}$, with a mean of $42 \mathrm{~s}$ (Free, 1957a).

Conflicts in the context of trophallaxis between workers are described when foreign bees enter a colony, in cage experiments and in queenless colonies. Butler and Free (1952) reported food regurgitations by intruders when attacked. Such offers are usually ignored by the attacking bees, but are occasionally accepted. Even if accepted, mauling does not necessarily stop. Conflicts in cages occur if two bees beg for food from each other or if one of the bees bites the tongue of the other one (Korst and Velthuis, 1982). Van der Blom (1991) demonstrated frequent loss of food by trophallaxis of bees that were under attack in queenless colonies. Attacks between workers of the same 
colony occur, when some workers start to develop ovaries and to lay unfertilized eggs that can develop into drones. The loss of food then makes it less probable that these workers can develop ovaries and, thus, become reproducing egglayers. Such a correlation of individual worker dominance with trophallactic behaviour was shown for Apis mellifera capensis by Hillesheim et al. (1989) although, in these experiments, dominance was already granted via the genetic background.

\section{WHAT IS TRANSFERRED FROM WHOM TO WHOM?}

Over the period of 1 day, large volumes of nectar, the main source for carbohydrates, can be brought into the hive by numerous flights of the forager bees. They perform their dances on the dancing floor, usually near the hive entrance (von Frisch, 1965). During and after this, they give the content of their crop preferentially to younger hivemates, to food-storer bees (Doolittle, 1907; Michener, 1974; Seeley, 1989) who again can give a part to other bees, but mainly deposit it into cells (Rösch, 1925). Later, this nectar is processed into honey.

Nixon and Ribbands (1952) quantified this flow of freshly harvested nectar. They provided six foragers with $20 \mathrm{~mL}{ }^{32} \mathrm{P}$ traced sugar water. It was shown that within $4 \mathrm{~h} 62 \%$ of the foragers and about one fifth of the total worker population received some of this food. This indicates numerous acts of feeding within the given period. The high proportion of foragers that had received food brought into the hive by the six hivemates collecting from the labelled artificial source can be explained by the intense food exchange on the dancing floor and by the provisioning of the bees before a new flight (von Frisch, 1965; Nuñez, 1970; Brandstetter et al., 1988; Farina, 1996).
During periods when the colony needs a lot of water, foragers can fly up to $2 \mathrm{~km}$ to collect it (Visscher et al., 1996). Some individuals might even specialise in water collection (Robinson et al., 1984). This water is transferred to other bees in the colony by trophallactic contacts and is deposited into cells (Park, 1923; von Frisch, 1965). It is used for several purposes, such as: to dilute honey in spring when brood rearing increases, to thermoregulate the colony during hot seasons (Park, 1946) and as a reserve if the metabolic water produced by a bee does not fully cover its needs (Louw and Hadley, 1985).

The food given to the brood consists of glandular secretions (hypopharyngeal glands and mandibular glands) and can also contain honey and pollen (Armbruster, 1960; Hanser and Rembold, 1964; Rembold, 1974; Kunert and Crailsheim, 1987). The proteinaceous part of the glandular secretions is produced by the hypopharyngeal glands (Brouwers, 1982; Lensky and Rakover, 1983; Knecht and Kaatz, 1990; Takenaka et al., 1990). When nurse bees are injected with a ${ }^{14} \mathrm{C}$ labelled amino acid, they subsequently incorporate this amino acid into the proteins of their hypopharyngeal gland (Crailsheim, 1990a). This protein is shared afterwards. Depending on the size of the colony, the age demography and the presence of drones, the queen, the drones and all age classes of workers receive quantities that can exceed all together the amount given to the brood (Crailsheim, 1991, 1992). Considering the fact that drones were usually provided by the same bees that also supply the brood with jelly, especially during periods when drones were not taking any food from the combs themselves, it is not surprising that they were also fed jelly. This was previously hypothesised by Free (1959).

Cannibalism of brood can occur in honeybee colonies for different reasons such 
as lack of proteinaceous food (Weiss, 1984) or brood diseases. Cannibalised nutrients can be transferred directly to other workers, or are converted to jelly and then distributed by trophallactic contacts, to workers, drones and the queen (Webster and Peng, 1987; Webster et al., 1987).

Together with protein (Rutz and Lüscher, 1974; Crailsheim, 1991) all of the queen's nutritional requirements (Allen, 1955, 1960; Haydak, 1970) are given to her by bees in her court (Allen, 1960; Free et al., 1992). The court is not a defined group, but consists simply of bees in the area surrounding the queen (Van der Blom, 1992). As she is on the brood nest most of the time in the breeding season, the bees feeding her will mostly be nurse bees (Prepelova 1928; Allen, 1955). A queen can also survive isolated and feed herself (Weiß, 1967). In colonies significant self-provisioning by the queen is only reported when she is not yet mated (Butler, 1954) or not laying at the moment (Prepelova, 1928). Also rare or absent is food donation by the queen to workers under natural conditions. In cage experiments, Pershad (1967) demonstrated such a transfer, and Crailsheim once saw a young queen offering food to begging drones, when they had escaped during insemination experiments and were sitting on a window (unpublished data). Butler observed submissive behaviour and food donation by a queen when removed from her own colony and put into another one (cited by Free).

Drones are fed by workers frequently (Free, 1957b; Örösi Pal, 1959; Mindt, 1962). In colonies workers of all ages do so (Free, 1957b), but preferentially nurseaged bees care for them (Prepelova, 1928). In an arena experiment when only worker had access to food, drones were kept alive for the longest periods when the workers were 10 days old (Alpatov and Saf'yanova, 1951). Drones ask for food from workers and from other drones, but from the latter no rewarding was observed (Ohtani, 1974). As seen in some experiments, young drones (Wachsmann and Crailsheim, 1994), and drones of all ages (Prepelova, 1928) were not observed taking food themselves from the combs. Probably all nutrients needed are fed to them [as is known for proteins (Crailsheim 1991, 1992)]. Reports about independent food consumption of older drones are not uniform. In arena experiments, fed drones regurgitated small amounts of previously ingested sugar water and deposited it on the ground, but genuine feedings from drones to workers were never observed (Hoffmann, 1966).

Honeybee queens provide pheromones that mediate and integrate the worker's activities (Velthuis, 1972, 1985; Slessor et al., 1988, 1990; Kaminski et al., 1990; Keller and Nonacs, 1993; Engels et al., 1997). These pheromones are not only evaporated and transferred by antennal contacts (Seeley, 1979; Ferguson and Free, 1980; Naumann et al., 1991), but also distributed upon their body surface. From there they are licked by bees surrounding the queen, the royal court (Allen, 1955). As individuals of the colony participate in the trophallactic flow, pheromones are distributed to all hive members in this way (Butler, 1954), although the transfer by antennal contact seems to be the most effective and fastest manner.

\section{FACTORS INFLUENCING THE TROPHALLACTIC FLOW}

The location of the bees inside the hive differs with their age and their position within the system of division of labour (Free, 1960; Seeley, 1982). Thus, bees of similar ages, performing the same task and being together in certain areas might have a bigger chance of meeting each other and to ask for food or to be asked. If 
a resulting contact leads to a food transfer, the probability of exchange between similarly aged bees is higher than between bees of different ages and functions. Experiments by Nixon and Ribbands (1952) confirm this possibility, demonstrating that sugar water brought into the hive by foragers (usually older bees) was distributed within $4 \mathrm{~h}$ preferentially to the older bees in the colony. Free (1957a) investigated this question of unequal distribution in observation hive experiments by observing donating and receiving in detail. He was able to demonstrate that bees of all ages feed partners of all ages, but that there is a preference to feed bees of a similar age. The only exceptions were freshly emerged bees and 1-day-old bees that did not donate food to any considerable extent, but received it as frequently as older age classes (Istomina-Tzvetkova, 1953; Free, 1957a).

There are some contradictions, especially from experiments in arenas. Moritz and Halmen (1986) placed differently aged bees into arenas with 8-10-day-old recipient bees. After feeding them with $20 \mu \mathrm{L}$ dyed sugar solution, the authors measured the amount and destination of the transferred food. Bees between 5 and 8 days old and bees older than 30 days were weak donors, whereas 1-day-old bees and bees between days 15 and 20 were the most effective ones. These results confirmed Pershad's (1966) data demonstrating the 2-4-day-old bees as potent donors, but opposed the result about 1-day-old ones being inactive donors.

These differences might be caused by a disturbance in behaviour due to the different ways of caging or the caging itself, the age of the recipients and their various relations to the donors or to group size in general (Pershad, 1967). Furthermore, different amounts (Free, 1957a; Montagner and Galliot, 1982) and different kinds of food in the crops of the bees have a strong influence on trophallactic behaviour.
Farina and Nuñez (1995) showed a dependency of donating contacts on the volume in their crop and on the concentration of previously ingested sucrose solutions. There was an increase in donating (number of contacts) up to a concentration of $30 \%$ sucrose, whereas a higher concentration of the food did not have a further positive effect.

In colonies that were not treated with smoke when taking the bees (smoke treating increases crop fillings) Free (1968) showed a mean crop weight of $7.2 \mathrm{mg}$. In some of the discussed experiments, the donors were fed before with volumes of food they might not have in their crop when acting in the colony. Such an abnormal crop load changes their ability and willingness to donate food. Also, the motivation of the recipients will differ depending on the situation (hive or various cage setups, their own crop fillings) and influences the number and success of trophallactic contacts.

Another reason for the contradictory results cited above may be the way of measuring trophallaxis. In some cases the number of trophallactic interactions were counted, in others the success of food transfer (dyes or radioactive label) was measured. According to Korst and Velthuis (1982), who demonstrated that many trophallactic contacts are not successful, these two ways of measuring will bring different results. Also, receiving only very small amounts of food, just sufficient for the bee to receive the information that was offered, but perhaps not enough to prove transfer by measuring the dyes in the experiment, can have importance (see below). Furthermore, temperature, or changes in temperature, are important factors in trophallactic interactions (Pershad, 1967).

Crailsheim, used the amount of proteinaceous food transferred as a measure for trophallaxis and found differences in the partners preferred as recipients. He 
showed that nurse-aged bees ( 9 days) donate jelly preferentially to their younger hive mates, but there might be an additional differentiation between the groups of older forager bees (see section below 'Purpose and importance'). Such a preference for younger bees was also observed in 21 day-old workers, although this age bee is not a typical 'nurse' any more (Hrassnigg and Crailsheim, 1996). In these two latter cases, the investigation of the transfer of protein instead of sugar water may be the reason for the distribution pattern differing from previous reports. As discussed for the transfer of nectar, the transfer of protein is also influenced by different experimental setups. Lass and Crailsheim (1996) showed that the synthesis and the amount of transferred labelled protein was reduced after long periods of caging, but that the frequency of feeding was not changed.

Some age classes of workers are fed more often than they donate food, whereas others donate more often than they receive. Exclusive receiving was shown for newly emerged bees (see above). For bees aged 5-12 days Free (1957a) demonstrated a tendency to receive food more often than to donate it, whereas it seems to be the opposite after day 16. Among a less specified group of bees 4-30 days old, no pronounced preference of donations over feedings was observed (IstominaTsvetkova, 1960).

In more recent experiments (Crailsheim et al., 1996), where only contacts were recorded that lasted more than $2 \mathrm{~s}$, nurse aged bees ( $7-12$ days) received and donated food somewhat less than once per hour during daytime and donated food only half as frequently during the night. On days with good weather conditions, foragers received food 2-3 times per hour and much less frequently around midnight. Donating of foragers occurred between one and two times per hour during daytime, and almost never in the hours around midnight. The reversed rate of donating and feeding is not really a contradiction to Free (1957a), as Free recorded just 16-20-day-old bees and Crailsheim et al. (1996) observed bees with a defined foraging status. The average frequency of 1-2 donations by a forager per hour during the foraging period of the day corresponds well with Seeley's (1989) observations of 1.4-1.5 bouts of nectar transfer per forager's return to the hive, estimating one flight per hour. Of course, the receiving and donating interactions (per hour) of foragers can deviate from the given average depending on the frequency and duration of flights during daytime and from the experimental design (observation during natural inflow/artificial feeding sites at various distances). For instance, transferred volume and contact time correlate positively with the crop load of a returning forager (Farina and Nuñez, 1991), and also the frequency of donations increased with the flow rate of an artificial sugar water source (indicating profitability). Between two foraging flights it varied between one and more than two donations per minute of presence in the hive. When donation rates were highest, this period lasted between 3 and 4 min, thus giving about eight donations after one flight (Farina, 1996).

As discussed above, foragers take food when starting on a foraging flight. If they already know the distance of their destination, they provide themselves according to this distance (Beutler, 1950; Istomina-Tsvetkova, 1960; Brandstetter et al., 1988). This food is partly the food they have previously collected or is given by other bees. The number of receiving contacts can be more frequent than donating ones. In experiments when foragers in good weather conditions donated food 1.8 times per hour, they received food 5.1 times (Riessberger and Crailsheim, 1997). Again, frequencies of feedings and their relation may differ depending on flight frequency, the distance covered, the qual- 
ity and amount of harvested food, and the situation in the colony.

Other factors influencing the trophallactic flow are the weather and the season. Even short periods of bad weather can influence brood production (Dustmann and von der Ohe, 1988; Riessberger and Crailsheim, 1997) and trophallactic flow (Riessberger and Crailsheim, 1997). The frequencies and durations of contacts varied during $1 \mathrm{~h}$, and most of them decreased after 1 day of rain. Surveying a longer period of rain gives a clear reduction of trophallactic flow (unpublished data). At the end of June, when colonies are well developed, and in early August, when colonies usually decrease brood production, hourly trophallactic interactions and their average durations were: 6.9 (23.9 s) and 4.5 (9.6 s), respectively (IstominaTsvetkova, 1960). The reduction of brood in colonies preparing for the winter will cause the age demography to change. At the same time, the colony will produce long living winter bees with a completely different age polyethism (Merz et al. 1979; Kunert and Crailsheim, 1988). This will definitely change the pattern of the trophallactic flow, as well.

In winter, brood rearing ceases or is drastically reduced in moderate and colder climate regions. In contrast to the foraging season, there are many bees that are several months old and according to brood conditions there might be few or no young bees. This of course changes the age structure of workers taking part in trophallactic interactions as discussed for the late summer. Pollen consumption and utilization is much reduced in general, especially when no brood has to be nursed (Crailsheim et al. 1993). Depending on the actual temperature, the bees form a more or less dense winter cluster (Wilson and Milum, 1927) to avoid heat loss (Heinrich, 1985) which influences mobility and partner availability. Trophallactic interactions between workers differ then from summer conditions (Moritz, 1984). To summarise the data about preferred partners, frequency and duration of trophallactic interactions within the group of workers, and the dependency on age, it must be stated that there are not only many difficulties in comparing various experimental setups, but furthermore there is quite a diversity of factors that influence trophallactic behaviour.

Starting from the second day after emergence workers can feed the queen (Allen, 1960). This onset of feeding ability again supports the finding that very young bees are involved in the trophallactic flow within a colony only as recipients and not as donors. The queen can receive almost five feedings within $\mathrm{l} \mathrm{h}$ during the most intense egg laying period. When a colony is preparing to swarm, the queen's feedings are reduced to almost zero (Allen, 1960). During winter the care for the queen is reduced (Free et al., 1992).

In arena experiments drone feeding by workers was quantified with radioactive tracer methods by Oertel and coworkers (1953). From a sucrose solution consumed (about $1 \mathrm{~mL}$ ) 20 workers gave $5 \%$ to ten drones within $3 \mathrm{~h}$, although the drones themselves had access to food. Levenets (1956) reported up to 25 feedings per hour during their first day of life, whereas Free (1957b) reported the highest frequencies on day 2 , and a steep decrease to the age of their first flight around day 8 . When drones are young, a frequency of four feedings per hour by workers was observed by Wachsmann (1994). As discussed for the workers, the differing results might be caused by using different experimental setups and definition of trophallactic contacts. From about day 6-8 onwards, drones feed mostly from honey cells (Free, 1957b; Örösi Pal, 1959) and were never seen to eat pollen (Prepelova, 1928; Szolderits and Crailsheim, 1993; Wachsmann and Crailsheim, 1994). When food becomes rare and/or weather is 
becoming colder in late summer, the care for the drones is reduced and finally stopped (Free and Williams, 1975). Such seasonal variations could be even shown in arena experiments. Workers fed drones more effectively in July than in August (Alpatov and Saf' yanova, 1951). When drones were bred in winter in a special experimental setup, arena experiments showed that they were fed less than in summer (Roger et al., 1987).

\section{GENETICS}

When 4-day-old bees in cages with 100 same-aged bees were tested as donors, $A$. m. ligustica and A. m. carnica behaved very similarly; 96 and $97 \%$ of the bees had received food from the donor bee within $4 \mathrm{~h}$. A. cerana and $A$. $m$. caucasica were also very effective ( 74 and $73 \%$ ), whereas $A$. m. mellifera donors gave food only to $30 \%$ of the bees in their cage (Kloft and Robinson, 1976). Although secondary trophallactic interactions could not be excluded in the experiments, these results indicate a different intensity of trophallaxis in various species and subspecies.

Arnold et al. (1996) examined the cuticle hydrocarbon composition in subfamilies (patrilines) of workers and demonstrated sufficient variability and genetic determinism to suggest they could be used as labels for subfamily recognition. Moritz and Hillesheim (1990) proved the ability of donors to discriminate and to prefer related over unrelated bees, and a significant variability of this ability between different patrilines. In nature, such situations occur only if bees drift from one colony to another one (Pfeiffer and Crailsheim, 1998). Trophallactic contacts (lasting more than $2 \mathrm{~s}$ ) of bees that had drifted during their first orientation or defecation flights, did not differ from contacts of bees that had not drifted (Pfeiffer and Crailsheim,
1997). Regarding this apparent contradiction it has to be stressed that Moritz and Hillesheim (1990) tested the amount of transferred food, while Pfeiffer and Crailsheim tested just the interactions. In a trophallactic bioassay Moritz and Heisler (1992) demonstrated the ability of bees, if only a few patrilines were present in the recipient group, to discriminate super and half sisters. Nevertheless, the importance of the ability to discriminate and to prefer related bees and its role in natural selection is not clear yet (Oldroyd et al., 1994).

\section{PURPOSE AND IMPORTANCE}

In addition to the role trophallactic behaviour plays under natural conditions, there is an additional component in the environment that is man-made. All toxins (e.g. Carbaryl; Wittmann, 1981) are distributed very efficiently to all members of a colony including the brood. This efficient distribution may also be used for the benefit of the bees when drugs against diseases or ectoparasites are applied (Moritz, 1984; Buren et al., 1992; 1993).

The trophallactic transfer of liquid food from the foragers to the food storer has economic importance. As the foraging bee does not have to spend time looking for empty cells to deposit the collected nectar, the transfer enables her to utilise a limited period during which a food source is available (and perhaps not yet detected by other colonies) more efficiently, thereby increasing the fitness of the colony.

During most time of the year colonies are well provided with nectar and honey. Each bee should be able to take food from the combs. For protein one could stress that on their first days young drones (Szolderits and Crailsheim, 1993) and workers (Moritz and Crailsheim, 1987) lack sufficient levels of proteolytic enzymes. That might be the reason that they do not consume much pollen 
(Szolderits and Crailsheim, 1993; Crailsheim et al., 1992; Wachsmann and Crailsheim, 1994). Nevertheless, during this period drones (Crailsheim et al., 1997) and workers (Haydak, 1937) develop their final protein equipment and seem to depend on the feedings of jelly from the middle-aged bees, who are well equipped to digest pollen and to process it (Moritz and Crailsheim, 1987); so does the queen who is fed most intensively during the period she is laying eggs (Allen, 1960). The queen is dependent mostly on a supply of highly valuable and easily digestible food, as her protein requirements are enormous. When she is laying eggs at a rate of more than 30 eggs per hour (Allen 1960), her daily production almost equals her own weight per day, but Nolan (1925) reports even more than double this egg laying rate. Her egg laying activity depends on the feedings of the workers. Not only the queen has a great need for protein, also forager bees have considerable protein turnover rates. The half-life of their protein is only $11-13$ days (Crailsheim, 1986), and even this age class lacks sufficient intestinal proteolytic activity (Moritz and Crailsheim, 1987) and does not consume pollen to any significant extent (Morton, 1951; Crailsheim et al., 1992). To meet their needs for protein they are fed by other worker bees including 9day-old nurses (Crailsheim, 1991, 1992) and older bees than these provide it (Hrassnigg and Crailsheim 1996). As foragers do not have significant amounts of pollen in their gastrointestines, they save weight which is important for a bee whose main duty is flying. The weighty pollen in the midgut of nurses amounts to $4 \mathrm{mg}$ (Crailsheim et al., 1992).

Sharing of protein does not have only nutritional importance (Crailsheim, 1990b) as the nurses even exchange this food within their own group. If a difference in quality occurs, and/or if there is a difference in willingness to donate this jelly to asking recipients, nurse-nurse trophallaxis may provide them with information about the supply of jelly and, thus, protein.

This information is not restricted to the nurse group. Other temporal castes, such as the foragers, might access the information about the protein status of the colony. Camazine (1993, Camazine et al., 1998) demonstrated that foragers react very quickly to a reduction or to an increase in pollen stores in their colony, even if they had no direct access to the pollen stores. They react, according to the needs, in foraging for pollen and, alternatively in switching to nectar if sufficient pollen is stored. Since just the smell of the pollen does not cause this reaction, Camazine hypothesised that the transfer of proteinaceous jelly might be the key for this regulation.

For the early provision of carbohydrates to young bees by older hive mates there is not such a clear nutritional necessity as with protein, because honey does not have to be processed by consumers as pollen does. Nevertheless, Rösch (1925) never saw very young workers taking honey themselves. This was also reported for young drones (Free, 1957b). Workers, emerging from their comb in an incubator, which are kept without nurses, do not develop well (Crailsheim and Stolberg, 1989). They have drastically reduced levels of amino acids in their haemolymph (Crailsheim and Leonhard, 1997). This indicates either a need for substances they cannot find on the comb, or an inability to feed and to digest sufficiently. Possibly in an intact colony the mixture of food given to them has an ideal composition regarding all other components such as vitamins and minerals, and when workers are giving food sufficiently, further provision is not necessary. This is certainly true for the laying queen, as she does not need to eat any other food than that given to her by the members of her court. 
Other roles of carbohydrate transfer are obvious. The foragers carry the nectar into the hive and share the information about the food source with other foragers, not only by the dances (von Frisch, 1965), but also by variation of trophallaxis. Since the effectivity of transfer, from foragers to other foragers and to workers with different functions in the hive depends on crop load, quality and flow rate of the food (all parameters indicating profitability) (Farina and Nuñez, 1991; Farina, 1996), the character of these donations can be interpreted by all recipients as information about the food source. A question still under discussion is whether or not body or nectar temperature can provide other bees with information about the profitability of a food source (Seeley and Towne, 1992). With increasing profitability of the food source (depending on sugar concentration and distance) the body temperature of the donor is higher (Stabentheiner, 1996). Foragers, collecting sucrose solution of 0.5 or 2 molar from a distance of $120 \mathrm{~m}$, differ in their thorax temperature by more than $2^{\circ} \mathrm{C}$. With increasing distance, when a constant concentration is fed, the temperature decreases. As the transferred solution is donated from the crop in the abdomen and has to pass the heated thorax and head, the temperature of the solution depends on the body temperature of the donor. Thus the temperature of the exchanged food might provide additional information about the profitability of the food source for the recipient (Stabentheiner et al., 1995).

Not only the character of the donations but also the asking for food by the prospective recipient provides information. The willingness of food storer bees to take the nectar depends on the easiness to store it. Such willingness is a signal for the foragers to increase or to decrease nectar foraging (Seeley, 1989; Seeley and Tovey, 1994) or even to perform dances (Nuñez, 1970). A lack of food storers but not reserves of stored honey seem to reduce nectar foraging activity (Fewell and Winston, 1996). The collection of water seems to be regulated in a similar manner (Lindauer, 1954).

As discussed above, trophallactic sharing is very effective. Within some hours $20 \mathrm{~mL}$ of sugar solution freshly collected by only six bees can be distributed to most members of a colony (Nixon and Ribbands, 1952). In this way, most of the bees have contact with all the food collected during 1 day and thus the information about the food income. Proteinaceous jelly produced by 100 nurses within one night, could be found in up to $15.6 \%$ of all members of large colonies (Crailsheim, 1992). These 100 focal bees were only a small part of the whole task group of nurses. Therefore, the jelly from just some hundred nurses would suffice to provide all hive mates with information about the protein status of the colony. Both flows, that of protein and of carbohydrates together, could provide the colony with information about the situation of food stores (Ribbands et al., 1952). This information about stores and needs for nutrients are of enormous importance for the regulation of egg laying by the queen (Allen, 1960), the brood care (Fewell and Winston, 1992) and the decision making process of what, if anything, a forager is going to collect (Seeley, 1989; Camazine, 1993, Fewell and Winston, 1996; Camazine et al., 1998). The sharing of information about food supplies by trophallaxis, is as important for the function of the colony as is the communication by pheromones and the dance language.

\section{ACKNOWLEDGMENTS}

I acknowledge the suggestions of Hayo Velthuis, the critical reading of the manuscript by Norbert Hrassnigg and the language corrections by Elizabeth Pessl-Rossi and the language editor of Apidologie. Many of the inves- 
tigations cited were supported by the Austrian Science Foundation.

\section{Résumé - Interactions trophallactiques chez l'abeille adulte (Apis mellifera L.).} La trophallaxie, échanges alimentaires réciproques entre adultes, s'observe régulièrement chez les abeilles mellifères. Les mâles et la reine ne sont que receveurs alors que les ouvrières sont à la fois donneuses et receveuses. Elles partagent le contenu de leur jabot et parfois aussi les secrétions de leurs glandes céphaliques. Le partage a lieu entre tous les membres de la colonie mais de façon inégale. Il est fonction de facteurs tels que le sexe et l'âge, l'abeille donneuse et la receveuse, la disponibilité en nourriture et sa qualité, l'heure, le temps et la saison. Ce flux de nourriture, principalement protéique, est d'une grande importance pour l'alimentation des jeunes ouvrières, comme des plus vieilles, des mâles et de la reine. En effet, ces abeilles ont besoin de protéines à des fins diverses mais consomment peu de pollen et le digèrent généralement mal. Cette déficience est compensée par un groupe particulier d'ouvrières, les nourrices, qui sont responsables de la consommation et de la transformation en gelée facilement assimilable. Ce système permet à la colonie d'avoir de nombreux membres qui n'ont qu'une capacité réduite de digestion. Les abeilles qui stockent la nourriture sont responsables du transport du nectar rapporté à la ruche. Elles en déchargent les butineuses et l'apportent dans les différentes parties de la ruche où il sera transformé en miel. Ceci fait gagner du temps aux butineuses qui peuvent ainsi l'utiliser à une prompte exploitation des ressources de nourriture. Le système de l'offre et de la demande permanentes de nourriture, outre son importance pour l'alimentation et son transfert vers les spécialistes, informe individuellement les abeilles de la situation alimentaire de la colonie. Ce moyen d'information est pour la communauté aussi important que les danses ou la communication par phéromones. (-) Inra/DIB/AGIB/EIsevier, Paris

\section{Apis mellifera / trophallaxie / division travail / alimentation / communication}

\section{Zusammenfassung - Trophallaxis bei} der Honigbiene. Trophallaxis, die gegenseitige Fütterung zweier erwachsener Individuen von Mund zu Mund, kann bei Honigbienen regelmäßig beobachtet werden. Drohnen und die Königin sind hierbei nur Konsumenten, Arbeiterinnen sind Konsumenten und Spender. Sie verteilen den Inhalt ihres Honigmagens und manchmal auch Syntheseprodukte ihrer Kopfdrüsen. Diese Verteilung erfolgt an alle Volksmitglieder, allerdings nicht gleichmäßig. Sie hängt von Faktoren wie dem Geschlecht und dem Alter sowohl der Spender als auch der Konsumenten, der Verfügbarkeit und Qualität von Nahrung, der Tageszeit, dem Wetter und der Jahreszeit ab. Für die Ernährung sowohl ganz junger und alter Arbeiterinnen als auch der Drohnen und Königin, hat dieser Futtersaftstrom sicherlich große Bedeutung, da diese Bienen für unterschiedlichste Zwecke viel Eiweiß benötigen, aber kaum Pollen fressen und ihn zumeist auch nur schlecht verwerten können. Dies kompensiert eine spezielle Gruppe von Arbeiterinnen, die Ammenbienen, die für den Konsum und die Verdauung des Pollens verantwortlich sind, aus den Eiweißbestandteilen Futtersaft produzieren und diesen an alle anderen Volksmitglieder verfüttern. Diese kommen daher mit einer reduzierten Fähigkeit zur Eiweißverdauung aus. Die Futterabnehmerinnen sind für den Transport des in den Stock eingetragenen Nektars verantwortlich. Sie übernehmen ihn von den Sammelbienen und bringen ihn in andere Teile des Stockes, wo er dann zu Honig verarbeitet wird. Dies erspart den Sammelbienen Zeit, die sie für eine rasche Ausnutzung der Nah- 
rungsressourcen nützen können. Zusätzlich zu der Bedeutung für die Ernährung und den Nahrungstransport stellt das permanente Geben und Nehmen ein System dar, das die einzelnen Bienen über die Versorgungssituation des Volkes informiert. Dieser Informationsgewinn ist für die Bienengemeinschaft von ähnlich großer Bedeutung wie die Bienentänze und die Kommunikation durch Pheromone. (C) Inra/DIB/AGIB/Elsevier, Paris

\section{Apis mellifera / Trophallaxis / Arbeits- teilung / Sprache / Ernährung}

\section{REFERENCES}

Allen MD (1955) Observations of honeybees attending their queen. Br J Anim Behav 3, 66-69

Allen MD (1960) The honeybee queen and her attendants. Anim Behav 8, 201-208

Alpatov V, Saf' yanova V (1951) A new method of studying the mutual feeding relations of bees. Bee World 32, 79

Armbruster L (1960) Gelée Royale. Arch Bienenkd $37,1-39$

Arnold G, Quenet B, Cornuet J-M, Masson C, De Schepper D, Estoup A, Gasqui (1996) Kin recognition in honeybees. Nature 379,498

Beutler R (1950) Zeit und Raum im Leben der Sammelbiene. Die Naturwissenschaften 37, 102-105

Brandstetter M, Crailsheim K, Heran H (1988) Provisioning of food in the honeybee before foraging. Biona Report (Nachtigall W, ed), Gustav Fischer, Stuttgart, 129-148

Brouwers EVM (1982) Measurement of hypopharyngeal gland activity in the honeybee. $J$ Apic Res 21, 193-198

Butler CG (1954) The importance of 'queen substance' in the life of a honeybee colony. Bee World 35, 169-176

Butler CG, Free JB (1952) The behaviour of worker honeybees at the hive entrance. Behaviour 4, 262-292

Calderone NW, Page RE Jr (1988) Genotypic variability in age polyethism and task specialization in the honey bee, Apis mellifera (Hymenoptera: Apidae). Behav Ecol Sociobiol 22, 17-25

Camazine S (1993) The regulation of pollen foraging by honey-bees. How foragers assess the colony need for pollen. Behav Ecol Sociobiol 32, 265-272

Camazine S, Crailsheim K, Hrassnigg N, Robinson GE, Leonhard B, Kropiunigg H (1998) Protein trophallaxis and the regulation of pollen foraging by honey bees. Apidologie 29, 113-126

Crailsheim K (1986) Dependence of protein metabolism on age and season in the honeybee (Apis mellifera carnica Pollm). J Insect Physiol $32,629-634$

Crailsheim K (1990a) Protein synthesis in the honeybee (Apis mellifera L.) and trophallactic distribution of jelly among imagos in laboratory experiments. Zool Jb Physiol 94, 303-312

Crailsheim K (1990b) The protein balance of the honeybee worker. Apidologie 12, 417-429

Crailsheim K (1991) Interadult feeding of jelly in honeybee (Apis mellifera L) colonies. J Comp Physiol B 161, 55-60

Crailsheim K (1992) The flow of jelly within a honeybee colony. J Comp Physiol B 162, 681-689

Crailsheim K, Stolberg E (1989) Influence of diet, age and colony condition upon intestinal proteolytic activity and size of the hypopharyngeal glands in the honeybee (Apis mellifera L.). $J$ Insect Physiol 35, 595-602

Crailsheim K, Leonhard B (1997) Amino acids in honeybee haemolymph. Amino Acids 13, $141-153$

Crailsheim K, Schneider LHW, Hrassnigg N, Bühlmann G, Brosch U, Gmeinbauer R, Schöffmann B (1992) Pollen consumption and utilization in worker honey bees (Apis mellifera carnica): dependence on individual age and function. J Insect Physiol 38, 409-419

Crailsheim K, Hrassnigg N, Gmeinbauer R, Szolderits MJ, Schneider LHW, Brosch U (1993) Pollen utilization in non-breeding honeybees in winter. I Insect Physiol 39, 369-373

Crailsheim K, Hrassnigg N, Stabentheiner A (1996) Diurnal behavioural differences in forager and nurse honey bees (Apis mellifera carnica Pollm). Apidologie 27, 235-244

Crailsheim K, Jin P, Pfeiffer K, Pabst MA (1997) Der Proteingehalt junger Drohnen der Honigbiene (Apis mellifera L.) Mitt Dtsch Ges Allg Angew Entomol, 11, 167-168

Doolittle GM (1907) Where do the field-bees deposit their loads? Am Bee J 42, 653-654

Dustmann J H, von der Ohe W (1988) Einfluß von Kälteeinbrüchen auf die Frühjahrsentwicklung von Bienenvölkern (Apis mellifera L.). Apidologie 19, 245-254

Engels W, Rosenkranz P. Adler A, Taghizadeh T, Luibke G, Francke W (1997) Mandibular gland volatiles and their ontogenetic patterns in queen honey bees, Apis mellifera carnica. J Insect Physiol 43, 307-313

Farina WM, Nuñez JA (1991) Trophallaxis in the honeybee Apis mellifera $\mathrm{L}$ as related to the profitability of food sources. Anim Behav 42, 389-394 
Farina WM, Nuñez JA (1995) Trophallaxis in Apis mellifera: Effects of sugar concentration and crop load on food distribution. J Apic Res 34, 93-96

Farina WM (1996) Food-exchange by foragers in the hive - a means of communication among honey bees? Behav Ecol Sociobiol 38, 59-64

Ferguson AW, Free JB (1980) Queen pheromone transfer within honeybee colonies. Physiol Entomol 5, 359-366

Fewell JH, Winston ML (1992) Colony state and regulation of pollen foraging in the honey bee Apis mellifera L. Behav Ecol Sociobiol 30, 387-393

Fewell JH, Winston ML (1996) Regulation of nectar collection in relation to honey storage levels by honey bees, Apis mellifera. Behav Ecol 7 . 286-291

Free JB (1956) A study of the stimuli which release the food begging and offering responses of worker honeybees. Br J Anim Behav 4, 94-101

Free JB (1957a) The transmission of food between worker honeybees. Br J Anim Behav 5, 4l-47

Free JB (1957b) The food of adult drone honeybees (Apis mellifera). BrJ Anim Behav 5, 7-11

Free JB (1959) The transfer of food between the adult members of a honeybee community. Bee World 40, 193-201

Free JB (1960) The distribution of bees in a honeybec (Apis mellifera L) colony. Proc Roy Entomol Soc London 35 A, 141-144

Free JB (1965) The allocation of duties among worker honeybees. Symp Zool Soc London 14, 39-59

Free JB (1968) Engorging of honey by worker honeybees when their colony is smoked. JApic Res $7,135-138$

Free JB (1987) Pheromones of Social Bees. Chapman and Hall, London, UK, 29-68

Free JB, Williams IH (1975) Factors determining the rearing and rejection of drones by the honeybee colony. Anim Behav 23, 65()-675

Free JB, Ferguson AW, Simpkins JR (1992) The behaviour of queen honeybees and their attendants. Physiol Entomol 17, 43-55

Frisch von $\mathrm{K}$ (1965) Tanzsprache und Orientierung der Bienen. Springer, Berlin

Galliot G, Azoeuf P (1979) Etude quantitative des transferts de nourriture entre ouvrières d'âge connu chez l'abeille domestique (Apis mellifica L). Insectes $S o c$ 26, 39-49

Hanser G, Rembold H (1964) Analytische und histologische Untersuchungen der Kopf- und Thoraxdrüsen bei der Honigbiene Apis mellifica. $Z$ Naturforsch 19 B, 938-943

Haydak MH (1937) The influence of a pure carbohydrate diet on newly emerged honeybees. Amn Entomol Soc Am 30, 258-262

Haydak MH (1970) Honey bee nutrition. Annu Rev Entomol 15, 143-156
Heinrich B (1985) The social physiology of temperature regulation in honeybees. In: Experimental Behavioral Ecology (Hölldobler and Lindauer, eds), G Fischer, Stuttgart, New York, Fortschritte der Zoologie, Bd 31, 393-406

Higo HA, Colley SJ, Winston ML, Slessor KN (1992) Effects of honcy bee (Apis mellifera $\mathrm{L}$ ) queen mandibular gland pheromone on foraging and brood rearing. Can Entomol 124, 409-418

Hillesheim E, Koeniger N, Moritz RFA (1989) Colony performance in honeybees (Apis mellifera capensis Esch.) depends on the proportion of subordinate and dominant workers. Behav Ecol Sociobiol 24, 291-296

Hoffmann I (1966) Gibt es bei Drohnen von Apis mellifica $\mathrm{L}$ ein echtes Füttern oder nur eine Futterabgabe? Z Bienenforsch 8, 249-255

Hrassnigg N, Crailsheim K (1996) Trophallaxis of proteinaceous jelly in middle-aged honey bees. Apidologie 27, 31 1-313

Huang ZY, Robinson GE (1992) Honeybee colony integration: worker-worker interactions mediate hormonally regulated plasticity in division of labor. Proc Natl Acad Sci USA 89, 11726-11729

Istomina-Tsvetkova KP (1953) Reciprocal feeding between bees. Pchelovodstvo 30,15-23 cited after Frec, 1959

Istomina-Tsvetkova KP (1960) Contribution to the study of trophic relations in adult worker bees. XVII Int Beekeeping Congr Bologna-Roma 2, 361-368

Kaminski L, Slessor KN, Winston ML, Hay NW, Borden JH (1990) Honeybee response to queen mandibular pheromone in laboratory bioassays. J Chem Ecol 16, 841-860

Keller L, Nonacs P (1993) The role of queen pheromones in social insects: queen control or queen signal? Anim Behav 45, 787-794

Kloft WJ, Robinson FA ( 1976) Food sharing behavior among caged workers of different races and species of honey bees Apis sp. Am Bee $J 116$, $106-107$

Knecht D, Kaatz HH (1990) Patterns of larval food production by hypopharyngeal glands in adult worker honey bees. Apidologie 21, 457-468

Kolmes S A (1985) A quantitative study of the division of labour among worker honey bees. $Z$ Tierpsychol 68, 287-302

Korst PJAM. Velthuis HHW (1982) The nature of trophallaxis in honeybees. Insectes Soc 29 , 209-221

Kunert K, Crailsheim K (1987) Sugar and protein in the food for honeybee worker larvae. In: Chemistry and Biology of Social Insects (Eder J, Rembold H, eds), J Peperny, Munich, 164-165

Kunert K, Crailsheim K (1988) Seasonal changes in carbohydrate, lipid and protein content in emerging worker honeybees and their mortality. J Apic Res 27, 13-21 
Lass A, Crailsheim K (1996) Influence of age and caging upon protein metabolism, hypopharyngeal glands and trophallactic behavior in the honey bee (Apis mellifera L.). Insectes Soc 43, 347-358

Lensky Y, Rakover Y (1983) Separate body compartments of the worker honeybee (Apis mellifera L). Comp Biochem Phssiol B 75, 607-615

Levenets NP (1956) How much food is used for rearing and maintaining drones. Pchelovodstvo 33, 53-54 cited after Free, 1959

Lindauer M (1952) Ein Beitrag zur Frage der Arbeitsteilung im Bienenstaat. $\mathrm{Z} \mathrm{Vgl} \mathrm{Phwiol} 34$, 299-345

Lindauer $M$ (1954) Temperaturregulierung und Wasserhaushalt im Bienenstaat. $Z$ Vg/ Physiol $36,391-432$

Louw GN, Hadley NF (1985) Water economy of the honeybee: A stoichiometric accounting. $J$ Exp Zool 235, 147-150

Merz R, Gerig L, Wille H, Leuthold R (1979) Das Problem der Kurz- und Langlebigkeit bei der Ein- und Auswinterung im Bienenvolk (Apis mellifica L): Eine Verhaltensstudie. Rev' Suisse Zool $86,663-67$

Michener CD (1974) The Social Behaviour of the Bees. The Belknap Press of Harvard University Press, Cambridge, Massachusetts

Mindt B (1962) Untersuchungen über das Leben der Drohnen, insbesondere Ernährung und Geschlechtsreife. Z Bienenforsch 6, 9-33

Montagner M, Pain J (1971) Etude préliminaire des communications entre ouvrières d'abcilles au cours de la trophallaxic. Insectes Soc 18, 177-192

Montagner M, Galliot G (1982) Antennal communication and food exchange in the domestic bee Apis mellifera L. In: The Biology of Srcial Insects (Breed MD, Michener CD, Evans ME, eds), Westview Press, Boulder, 302-306

Moritz RFA (1984) Drug distribution in systemic therapy of ectoparasitoses of Apis mellifera $\mathrm{L}$. Anim Res Develop 20, 106-119

Moritz B, Crailsheim K (1987) Physiology of protein digestion in the midgut of the honeybce (Apis mellifera L). I Insect Phrsiol 33, 923-931

Moritz RFA, Hallmen M ( 1986$)$ Trophallaxis of worker honeybees (Apis mellifera $\mathrm{L}$ ) of different ages. Insectes SoC 33, 26-31

Moritz RFA, Heisler T (1992) Super and half-sister discrimination by honey bee workers (Apis mellifera $\mathrm{L}$ ) in a trophallactic bioassay. Insectes $S o c$ 39, 365-372

Moritz RFA, Hillesheim E (1990) Trophallaxis and genetic variance of kin recognition in honey bees, Apis mellifera L. Anim Behav 40, 641-647

Morton K (1951) The food of worker bees of different ages. Bee World 32, 78-79

Naumann K, Winston ML, Slessor KN, Prestwich GD, Webster F (1991) Production and transmis- sion of honey bee queen (Apis mellifera $\mathrm{L}$ ) mandibular gland pheromone. Behav Ecol Sociobiol 29, 321-332

Nixon HL, Ribbands CR (1952) Food transmission within the honeybee community. Proc Rov $S o c B$ $140,43-50$

Nolan JW (1925) The brood rearing cycle of the honeybee. USDA Bull 134, 1-55

Nuñez JA (1970) The relationship between sugar flow and foraging and recruting behaviour of honeybees (Apis mellifera L.). Anim Behav 18, $525-538$

Oertel E, Emerson RB, Wheeler HE (1953) Transfer of radioactivity from worker to drone honey bees after ingestion of radioactive sucrose. Ann Entomol Soc Am 46, 596-598

Ohtani T (1974) Behaviour repertoire of adult drone honeybees within observation hives. J Fac $S \mathrm{Ci}$ Hokkaido Uni, VI Zool 19, 709-721

Oldroyd BP, Rinderer TE, Schwenke JR, Buco SM (1994) Subfamily recognition and Task specialisation in honey bees (Apis mellifera L) (Hymenoptera:Apidae). Behar Ecol Sociobiol $34,169-173$

Orösi PZ (1959) The behaviour and nutrition of drones. Bee World 40, 141-146

Pain J, Roger B, Douault P (1978) Les transferts de nourriture chez les Abeilles (Apis mellifica ligustica $S$.) des trois castes dont les deux antennes ont été amputées de quatre articles distaux. $C R$ Acad Sci Paris, Série D, 286 |455-1458

Park W (1923) Behavior of water carriers. Am Bee J, 63,553

Park W (1946) Activities of Honeybees. In: The Hive and the Hone yee (Grout RA, ed), Dadant and Sons, Hamilton, IL, USA

Pershad S (1966) L'influence de l'âge sur les échanges de nourriture entre les ouvrières d'abeilles Apis mellifera. Insectes Soc 13. 323-328

Pershad S (1967) Analyse de diftérents facteurs conditionnant les échanges alimentaires dans une colonie d'abeilles Apis mellifera $\mathrm{L}$ au moyen du radio-isotope $\mathrm{P}^{32}$. Ann Abeille 10, 139-197

Pfeiffer KJ, Crailsheim K (1997) The influence of drifting on the behaviour of nurse bees. Apidologie 28, 198-200

Pfeiffer KJ, Crailsheim K (1998) Drifting of honeybees. Insectes Soc 45, in press

Prepelova L (1928) The nurse bees. Opyt Pas 3, 551-557 cited after Free 1959

Rembold H (1974) Die Kastenbildung bei der Honigbiene, Apis mellitera $\mathbf{L}$, aus biochemischer Sicht, Sozialpolsmorphismus bei Insekten. Wissenschaftliche Verlagsgesellschaft $\mathrm{mbH}$, Stuttgart, 350-403

Ribbands CR (1952) The division of labour in the honeybee community. Proc Roy Soc London B $140,32-43$ 
Ribbands CR, Kalmus H, Nixon H L (1952) New evidence of communication in the honeybee colony. Nature 170, 438-440

Riessbeger U, Crailsheim K (1997) Short-term effect of different weather conditions upon the behaviour of forager and nurse honey bees (Apis mellifera carnica Pollm). Apidologie 28, 41 I-426

Robinson GE (1987) Regulation of honey bee age polyethism by juvenile hormone. Beha' Ecol Sociobiol 20, 329-338

Robinson GE, Underwood BA, Henderson CE (1984) A highly specialized water-collecting honey bee. Apidologie 15, 355-358

Roger B, Douault P, Pain J (1978) Étude des transferts de nourriture au cours des saisons chez les mâles d'abeilles (Apis mellifica ligustica Spin) au moyen d'un radio-isotope ( $\left.{ }^{198} \mathrm{Au}\right)$. Comparaison entre les trois castes. $C R$ Acad Sci Paris, Série D, 286, 1149-1152

Rösch GA (1925) Untersuchungen über dic Arbeitsteilung im Bienenstaat I Teil: Die Tätigkeit im normalen Bienenstaate und ihre Beziehung zum Alter der Arbeitsbienen, $Z$ Vgl Physiol 2, 571-631

Rothenbuhler WC, Page RE Jr (1989) Genetic variability for temporal polyethism in colonies consisting of similarly-aged worker honey bee. Apidologie 20, 433-437

Rutz W, Lüscher M (1974) The occurrence of vitellogenin in workers and queens of Apis mellifica and its transmission to the queen. I Insect Physiol 20, 897-909

Seeley TD (1979) Qucen substance dispersal by messenger workers in honeybec colonies. Behav Ecol Sociobiol 5, 391-415

Seeley TD (1982) Adaptive significance of the age polyethism schedule in honeybee colonies. Behav Ecol Sociobiol 1 1, 287-293

Seeley TD (1989) Social foraging in honey bees: how nectar foragers assess their colony's nutritional status. Behar Ecol Sociobiol 24, 181-199

Seeley TD, Towne WF (1992) Tactics of dance choice in honey bees: do foragers compare dances? Behav Ecol Sociobiol 30, 59-69

Seeley TD, Tovey CA (1994) Why search time to find a food-storer bee accurately indicates the relative rates of nectar collecting and nectar processing in honcy bee colonies. Anim Behav 47. $311-316$

Slessor KN, Kaminski LA, King GGS, Borden JH, Winston M (1988) Semiochemical basis of the retinue response to queen honey bees. Nature $332,354-356$

Slessor KN, Kaminski LA, King GGS, Winston M (1990) Semiochemicals of honeybee queen mandibular glands. J Chem Ecol 16, 851-860

Stabentheiner A (1996) Effect of foraging distance on the thermal behaviour of honeybees during dancing, walking and trophallaxis. Ethology 102 , $360-370$
Stabentheiner A, Kovac H, Hagmüller K (1995) Thermal behaviour of round and wagtail dancing honeybees. I Comp Phwiol B 165, 433-444

Szolderits MJ, Crailsheim K (1993) A comparison of pollen consumption and digestion in honeybee (Apis mellifera carnica) drones and workers. $J$ Insect Physiol 39, 877-881

Takenaka T, Miwa S, Echigo T (1990) Changes of protein content and enzyme activity in hypoharyngeal glands during lifespan of honeybee workers (Apis mellifera L). Bull Fac Agric Tamagama Univ 30, 1-8

Van Buren NWM, Marien AGH. Velthuis HHW (1992) The role of trophallaxis in the distribution of Perizin in a honeybee colony with regard to the control of the Varroa mite. Entomol Exp App/ 65, 157-164

Van Buren NWM, Marien AGH, Velthuis HHW (1993) The effectiveness of systemic agents used to control the mite Varroa jacobsoni, in colonies of the honey bee, Apis mellifera depends on food distribution patterns. Apidologie 24, 33-4.3

Van der Blom $\mathbf{J}$ (1991) Social regulation of egg-laying by queenless honeybee workers (Apis mellifera L.). Behav Ecol Sociobiol 29, 341-346

Van der Blom J (1992) Individual involvement in queen-attending of worker honeybees. Insectes Soc $39,237-249$

Velthuis HHW (1972) Observation on the transmission of queen substances in the honeybee colony by the attendants of the queen. Behaviour 41 , $105-129$

Velthuis HHW (1985) The honeybee queen and the social organisation of her colony. In: Experimental Behavioral Ecology (Hölldobler, Lindauer, eds), G Fischer Stuttgart, New York, Fortschritte der Zoologie. Bd 31, 343-357

Visscher PK, Crailsheim, K. Sherman G (1996) How do honey bees (Apis mellifera) fuel their water foraging flights?. I Insect Physiol 42, 1089-1094

Wachsmann A (1994) Das Individualverhalten von Drohnen (Apis mellifera) vor der Geschlechtsreife. Master thesis at the Zoologisches Institut der Karl-Franzens-Universität Graz, Austria

Wachsmann A. Crailsheim K (1994) The behaviour of young drones (Apis mellifera carnica Pollm) inside the hive. Apidologie 25, 465-466

Webster TC, Peng YS (1987) Passage of cannibalized tissue among honey bee (Hymenoptera: Apidae) colony members. Am Entomol Soc Am 80 , 814-819

Webster TC, Peng YS, Dulfey SS (1987) Conservation of nutrients in larval tissue by cannibalizing honey bees. Physiol Entomol 12, 225-231

Weiss K (1984) Regulierung des Proteinhaushaltes im Bienenvolk (A pis mellifica L.) durch Brutkannibalismus. Apidologie 15, 399-354 
Wilson HF, Milum VG (1927) Winter protection for the honey bee colony. Res Bull Wis Agric Exp Sta $75,1-47$

Winston M(1987) The Biology of the Honey Bee. Harvard Univ Press, Cambridge

Winston ML, Higo HA, Slessor KN (1990) Effect of various dosages of queen mandibular gland pheromone on the inhibition of queen rearing in the honey bee (Hymenoptera: Apidae). Am Entonol Soc Am 83, 234-238

Winston ML. Slessor KN, Willis L, Naumann K. Higo HA, Wyborn MH, Kaminski LA (1989)
The influence of queen mandibular pheromones on worker attraction to swarm clusters and inhibition of queen rearing in the honcy bee (Apis mellifera $\mathrm{L}$ ). Insectes Soc $36,15-27$

Winston M L, Higo H A, Colley S C, Pankiw T, Slessor K N (1991) The role of queen mandibular pheromone and colony congestion in honey bee (Apis mellifera) reproductive swarming. $J$ Insect Behav 4, 649-660)

Wittmann D (1981) Tracerversuche zur Passage von Carbaryl durch Apis-Arbeiterinnen. Mitt Dtsch Ges Allg Angew Entomol 3, 184-186 